\title{
Managing sustainability of national security: Implications for Ukraine
}

\author{
Ihor Todorov ${ }^{1}$, and Nataliia Todorova ${ }^{1, *}$ \\ ${ }^{1}$ Uzhhorod National University, Universytetska St, 14, Uzhhorod, Zakarpattia Oblast, 88000, Ukraine \\ ${ }^{1}$ Uzhhorod National University, Universytetska St, 14, Uzhhorod, Zakarpattia Oblast, 88000, Ukraine
}

\begin{abstract}
The article studies the interrelated categories of national security and sustainable development, which are currently the object of special attention of government institutions, civil society, political parties, territorial communities, etc. The purpose of the study is to specify the topical issues associated with sustainable development of the national security, building on the international experience in this area, and to determine the locally adaptable ways of ensuring sustainability of the national security of Ukraine. The process of sustainable development of national security is to be more effective when there is a clear idea of its structural and functional elements, direct and indirect ties among them. The synergy of national security with the implementation of the 2030 Sustainable Development Goals is able to ensure comprehensive modernization in accordance with today's requirements and strengthen the level of welfare and security of citizens. The integrated level of national security of Ukraine correlates with the goals of sustainable development. The country's stability and its resistance to national security threats is a necessary condition for implementing a purposeful sustainable development strategy for 2030. Successful implementation of sustainability tasks for Ukraine is possible provided there exist unity and capacity of state power and society.
\end{abstract}

\section{Introduction}

The development of Ukraine as a democratic, independent and sovereign state is primarily concerned with ensuring its national security. Modern challenges have led to the beginning of a radical transformation of the world economic and social order. Multi-vector geopolitical influences on Ukraine in the face of ineffective guarantees of its national security, critical external dependence of the national economy cause the country's vulnerability, weaken its role as an entity on the international arena and push it to the periphery of world politics, the so-called grey security zone.

At the same time, internal challenges to national security remain complicated. Russia's aggressive actions to deplete the Ukrainian economy and undermine socio-political stability with the ultimate goal of destroying Ukrainian statehood, inefficiency of the national security system, corruption and imperfection of the public administration system, costly economic model and depletion of state financial resources, lower living standards, distortions of democratic procedures, which artificially hinder the processes of personnel renewal in state bodies, cause weakness, and sometimes inability of the authorities to perform their functions,

*Corresponding author: nataliya.todorova@,uzhnu.edu.ua 
especially in protecting human and civil rights and freedoms, and result in the growing public distrust to the government.

Sustainability is understood as a management approach focusing on the systematic and reasonable use of available resources and operating socially responsibly. Transformation of the national security doctrine, strategic planning, decision making, and institutional behaviours according to a sustainability-based approach causes them all to mutually ally in supporting sustainability.

The purpose of this study is to specify the topical issues associated with sustainable development of the national security, building on the international expertise in this area, and to determine the locally adaptable ways of ensuring sustainability of the national security of Ukraine.

\section{Literature Review}

For quite a time, the issues of sustainability of national security and its main components have been in the limelight of the research in the works by scholars of various fields of knowledge: economists and political students, experts in power engineering and lawyers, military and public administration specialists. They unanimously determined a clear connection between security and sustainability implying that these are two different and inseparable concepts that affect each other.

It was the 1987 Brundtland Report [1] that is believed to spur the application of sustainability to state security. Having emphasised the significance of sustainable development to regional security, this document outlined the risks of spontaneous chaotic development. The 1994 Human Development Report [2], issued by the UN Development Program, gave the definition of the state security in terms of human security, launching the research of human security contribution to ensuring the state stability. The need to analyse the dependence of state security on human security and environmental sustainability acted as a spur to analysing the national security in view of sustainable development, its challenges and their causes. This idea was further developed in the works by Smith [3], Kirshner [4], Blackburn [5], and others.

The sustainability concept has been explored at the strategic, operational and tactical levels of national security, and the importance of focusing international and national priorities on identifying and preserving the resource base necessary to maintain security and mitigate threats has been highlighted [6]. Hartman [7] studies the evolution of the US Army sustainability program, and the impact of sustainability on national security strategic objectives. Butts and Bankus consider sustainability as a "valuable lens for viewing the national security landscape of the United States" and "a foundation for developing U.S. national security policy" [8], providing the opportunity to regard the national security at two levels: (a) at the national level, when sustainability informs national security policy to sustain the country's economy and defence capabilities; and (b) at the regional level, when it also informs the application of the national security elements to international security objectives $[8,9]$.

According to Khagram [10], the term "sustainable security" was introduced to emphasise the significance of consolidating state, human, and environmental security and refer to the underlying causes of insecurity. Various aspects of national security were researched in view of managing their sustainability given the interrelation between the environment and the economy remains the core of the nation-state sustainable development [11]. Environmental dimension of national security was extensively dealt with by S. Wasserman Goodman [12], Allenby [13] and others. Energy security as a component of the country's national security was evaluated by Dźwigoł et al. [14], Polozova et al [15]. Proceeding from the fact that fourth industrial revolution is blurring the borders between the physical, digital, and biological 
spheres, Lutterbeck [16] emphasised the convergence of internal and external security in western Europe, while Limba et al. [17] argued that this phenomenon disrupts the established patterns and opens new paths to development, challenging the holistic approach to national security issues, hybrid threats, economic crises, social inequalities, and labour migration being among the main ones.

The domestic researchers also studied sustainable development in the context of various aspects of national security. In particular, studies in this direction were carried out by V. Antonov [18], O. Dzioban et al. [19], V. Lipkan [20], O. Potekhin [21], G. Sytnyk [22], S. Tabachnikov [23], Y. Kharazishvili [24, 25], Sukhodolia [26, 27] and others. Transparent cognitive technologies were considered in view of ensuring sustainable society development [28]. Dalevska et al. worked out a model for estimating social and economic indicators of sustainable development [29]. Shapoval et al. [30] reviewed standards of state policies in terms of the national security of the European Union countries to conclude that the successful provision of national security strategy and approach depends on the sustainability and strength of their national economies. The authors maintained that in conditions of throatcutting global competition and world economic divergence the country should have a sustainable economy in order to successfully defend its national interests. This leads to the necessity for the nation-state not only to elaborate a national security concept, grounded on the global state-of-the-art experience, but, primarily, to update its home and foreign policies with a view to protecting all national security actors.

\section{Methodology}

The ideas and conceptual approaches of the mentioned publications contributed to developing a systematic understanding of the interaction and interrelation of the priorities of this study. There was substantiated and applied the semantic filter the "national security of Ukraine" and "sustainable development" to analyse their causal chains. The critical analysis of the official documents, laws and decrees adopted and sober reflection on the current measures taken in Ukraine to ensure sustainability of the national security informed this research. In view of the focus on managing sustainability of national security, the subject of the study is the state-of-the-art developments in this area globally and the interaction of national security of Ukraine with its current ways and prospective aspirations to implement sustainable development goals.

\section{Results}

From the first days of Ukraine's existence as an independent state, the Declaration on the State Sovereignty of Ukraine clearly defines the vital interests of this country, which reflect the fundamental values and aspirations of the Ukrainian people, their needs in decent living conditions, and civilized ways of creating them. In particular, it is about creating a civil society, improving the efficiency of state authorities and local self-government, developing democratic institutions to ensure human rights and freedoms, achieving national harmony, political and social stability, guaranteeing the rights of the Ukrainian nation and national minorities, ensuring state sovereignty, territorial integrity and inviolability of borders, creation of self-sufficient socially oriented market economy, provision of ecologically and technologically safe living conditions of society [31].

Practice shows that sustainable development and security are two sides of the process of society life. The inseparability of the functions of development and security is explained, first of all, by the unity of all processes of human activity, the division of which into separate spheres, branches, directions is conditional to facilitate cognition of the reality, but has no 
direct relation to it. Development involves increasing the capabilities and resources of man, society and the state in various spheres of life. It is provided by legal, political, economic, and other means that do not violate the mechanisms of functioning and reproduction of life developed by mankind. The secondary nature of security does not diminish its role and significance in the objective reality. In other words, without security, all human activity is pointless. The concept of "security" as a complex multifaceted social phenomenon has a specific historical character and is closely related to all forms and directions of interaction in the system "nature - man - society". The content of various interactions among the elements of this system is of greatest significance. They reflect the processes of influence of different objects on each other, their mutual conditionality, change of state, as well as the generation of one object by another. Interaction determines the development of all objects of the surrounding reality. It is the interaction of opposites that is the source, basis and ultimate cause of origin, self-movement and development. The category of "interaction" is important in the process of cognition of natural and social phenomena, the basis of a systematic approach to cognition of the world and social practice in all spheres of life, including security. Security of human existence, or personal and property security is the protection of people from negative influences of various kinds that can harm their body and property. Environmental safety is the protection of man and the environment from the negative effects of natural and man-made nature. It is provided by the study and knowledge of natural phenomena and preventive measures in case of natural disasters of various kinds. These types of security relate to a human being as a biological entity and reflect the necessity to protect the inherent nature of their physiological needs, especially the need for self-preservation. It is these types of security from the very beginning of man and civilization that have been and still are in the spotlight, and many even fully identify with the general category of "security". Ensuring these types of security is an area of theoretical and practical activities of a number of sciences and special institutions of society and the state.

National security or security of the nation implies the protectability of the vital interests of the individual, society and the state in various spheres of life from internal and external threats, which ensures the sustainable development of the country. In this case, security means the ability of an object or system (nature, man, society, state, etc.) to preserve its qualitative certainty and the ability to perform its functions under the influence of negative factors. National security is a complex multifaceted concept and includes the following types of security: political, economic, military, state, information, scientific and technological, economic, epidemic, financial, fire, food, security of cultural development of the nation. Objects of national security include: national interests, national values, structural elements of the national security system, their properties and relations that are protected from threats.

Consequently, there are three levels of basic security: (a) a man, his rights and freedoms; (b) the society, its spiritual and material values; (c) the state, its sovereignty, constitutional order, territorial integrity and inviolability of borders. The subjects of national security should own properties that ensure the protection of security objects.

The main subject of national security is the state, which, according to the Constitution of Ukraine, ensures the security of every person and citizen, their life, health, honour, dignity, personal integrity on the territory of Ukraine and abroad. The state performs its functions in the field of national security through the legislative, executive and judicial authorities, nongovernmental organizations and citizens. Ensuring the security of the individual, society and the state is based on separating powers of the main actors of the national security system. The Ukrainian people - citizens of Ukraine of all nationalities - in elections, referendums, as well as through public authorities and local governments express and implement their vision of the national interests of Ukraine, ways to protect them, draw the attention of public and state institutions to dangerous phenomena and processes in various spheres of life. The Verkhovna Rada of Ukraine, within its powers defined by the Constitution of Ukraine, carries out 
legislative regulation and control over the activities of public authorities and officials in exercising their respective powers in the field of national security. The President of Ukraine, as the head of state, the guarantor of state sovereignty, territorial integrity of Ukraine and the Supreme Commander-in-Chief of the Armed Forces of Ukraine and the Chairman of the National Security and Defence Council of Ukraine provide top leadership in national security and defence. The National Security and Defence Council of Ukraine is the coordinating body for national security and defence under the President of Ukraine, coordinates and controls the activities of public authorities in the field of national security and defence. The Cabinet of Ministers of Ukraine, as the highest executive body, takes measures to ensure the rights and freedoms of man and citizen, defence, national security, public order and the fight against crime. An important role is assigned to ministries and other central executive bodies, which, within their powers, available budgetary and extrabudgetary funding, ensure the enforcement of the laws of Ukraine, decrees of the President of Ukraine and other legal acts. In the field of national security, they provide for establishing, supporting and engaging the forces and means of national security, as well as managing their activities.

The Constitutional Court of Ukraine decides on the conformity of laws and other legal acts in the field of national security and gives their official interpretation. Courts of general jurisdiction administer justice in the field of national security of Ukraine, and the Prosecutor's Office of Ukraine exercises its powers in the field of national security. The National Bank of Ukraine develops and implements issuance and credit policy in the interests of Ukraine's national security. An important role in the implementing national security belongs to the military organizations of the state, which include: the Armed Forces of Ukraine, the National Police, the Security Service of Ukraine; National Guard; border troops, military units of the Ministry of Emergencies of Ukraine, which within their powers ensure the defence of Ukraine, protection of its sovereignty, territorial integrity and inviolability of its borders, counteract external and internal threats of a military nature, fight organized crime, combat organized crime catastrophes, natural disasters, dangerous social conflicts and other cataclysms that may occur [32]. In essence, all components of Ukraine's national security are to be organically linked to sustainable development.

In September 2015, the UN Summit on Sustainable Development was held in New York. The final document of the Summit "Transforming our world: the agenda for sustainable development until 2030" approved 17 sustainable development goals, all of which, directly or indirectly, are related to national security [33].

Ukraine as a UN member state has joined the global process of ensuring sustainable development. During 2016-2017, a large-scale and comprehensive process of adapting the Sustainable Development Goals to the Ukrainian context continued. Each global goal was revised, taking into account the specificity of national development. This work resulted in 86 specified tasks of national sustainable development. National targets, indicators for monitoring the implementation of tasks and targets to be achieved by 2030 are reflected in the National Report "Sustainable Development Goals: Ukraine". The established national set of tasks and indicators of the Sustainable Development Goals provides a solid basis for further comprehensive monitoring. In total, 17 goals and 86 national tasks are incorporated in 145 regulations of the Government. 1052 tasks and 3465 measures enshrined in these acts are aimed at implementing goals and objectives. On September 30, 2019, the President of Ukraine issued a Decree "On the Sustainable Development Goals of Ukraine until 2030", which supported the achievement of global sustainable development goals and the results of their adaptation to the specificity of Ukraine's development set out in the National Report "Sustainable Development Goals: Ukraine" [34].

At the present stage of development, the Ukrainian state has faced threats and challenges that need to be addressed immediately, the most pressing of which is Russian military aggression; temporary occupation of the territory of the Autonomous Republic of Crimea and 
the city of Sevastopol and parts of Donetsk and Luhansk regions, destabilization of the situation in the Baltic-Black Sea-Caspian region; concentrating military groups near the borders of Ukraine and in the temporarily occupied territory of the country; information and psychological warfare, humiliation of the Ukrainian language and culture, falsification of the Ukrainian history, formation of an alternative reality by the Russian mass media that distorts the information picture of the world. In this context, the priority strategic tasks of Ukraine's national security policy are to restore the country's territorial integrity and a set of democratic institutions throughout its territory, consolidate the Ukrainian political nation, form a national identity, unite all citizens of Ukraine and all its regions, and reintegration of the temporarily occupied territories after their liberation. Since 2020, the spread of coronavirus disease (COVID-19) has been added to these challenges and has exacerbated and opened up systemic problems in the field of health, biosafety, social protection, and the state's lack of readiness to act in emergencies.

Until recently, national security was understood exclusively as the preservation of the sovereignty and territorial integrity of the nation-state, ensuring its viability in the face of the armed force threat by other actors in international relations. In fact, national security must be seen in a much broader context, organically linked to sustainable development. National security characterizes the organization, functioning and development of society, providing the necessary conditions and opportunities to preserve its integrity and quality, protection and realization of national interests, timely neutralization and prevention of dangers and threats to these interests for the population. The essence of national security is manifested, first, in the constant increase of various resources and opportunities of society, their rational use for pursuing national interests, sustainable and progressive development of the country; secondly, in the functioning of an effective system of public law counteraction to dangers and threats to national interests, and, thirdly, in the dynamics of the national security system, its ability to timely identify and neutralize threats to national interests.

The Law of Ukraine "On National Security of Ukraine" defines the legal category "national security of Ukraine" as the immunity of state sovereignty, territorial integrity, democratic constitutional order and other national interests of Ukraine to real and potential threats. The concept 'threat' is understood as phenomena, trends and factors that make, or might make, it impossible or difficult to pursue the national interests and preserve the national values of Ukraine. In this law, the term "state security" is used as the immunity of state sovereignty, territorial integrity and democratic constitutional order and other vital national interests to real and potential threats of a non-military nature [35]. In addition to the Law "On National Security of Ukraine", the basic legal acts that reveal the issues of ensuring the national security of Ukraine are the National Security Strategy of Ukraine [36], the Military Doctrine of Ukraine [37], the Strategic Defence Bulletin of Ukraine [38].

It should be emphasized that the security of the individual is one of the conditions of security of society and the state, based on the principle of priority of man, his rights and freedoms over other constitutional values in the triad of national security objects (individual, society, state), as it is the guarantee of sustaining the country's interests that is of strategic nature for the national security of the state. The security of society characterizes the protectability of the interests of the individual involved in the relevant social processes. All this correlates with the goals of sustainable development.

The UN has developed a classification of public safety, which defines its basic levels, including: economic, provision, social, political, environmental, personal security, health. State security characterizes the level of the state's protection from internal and external threats through using a set of political, economic, social, military, informational and legal measures that serve to ensure the sustainable development of society. Based on implementing the provisions of the National Security Strategy of Ukraine, there is an urgent need to formulate effective measures to build a modern system of resource provision of national security of 
Ukraine, taking into account the experience of leading countries and national characteristics. It is national stability that is the key element of total defence. As a rule, allowing for certain national approaches to organizing and constructing total defence, five interrelated components are considered: military defence, civil defence, civil readiness, economic defence, and psychological defence. This approach is partly reflected in the National Security Strategy of Ukraine, namely in the part that Ukraine will introduce a national system of resilience, which implied the readiness of society and the state to repel aggression, resilience of critical infrastructure, cyber resilience and so on. Protection of the sovereignty and territorial integrity of Ukraine is the most important function of the state and the concern of the entire Ukrainian people, which is the basis of a comprehensive approach to the defence of Ukraine in the face of an existential military threat. The concept of total (comprehensive) defence is built on the principles of patriotism, a common national idea, historically determined values of the people. Undoubtedly, this approach to building a sustainable security model of the state certainly deserves to be implemented taking into account national specific features in the modern realities of Ukraine's counteraction to armed aggression by the Russian Federation [36].

National security of Ukraine is ensured by conducting a balanced state policy in accordance with duly adopted doctrines, concepts, strategies and programs in the political, economic, social, military, environmental, scientific and technological, information and other spheres. The choice of specific means and ways to ensure the national security of Ukraine is conditioned by the need to take timely measures adequate to the nature and scale of threats to national interests. Approaching the set goals of national security is possible only through the consistent implementation of the constitutionally enshrined course for Ukraine's EuroAtlantic and European aspirations. It is this course that is able to provide the necessary transition to an intensive and qualitatively new way of organizing security and development of the country. The solution to this problem should be based on new technologies for elaborating protective managing effects using the principles of intelligent management.

Ensuring national security is today central to the strategically significant challenges for the sustainable development of the country. It reflects the complexity of the transformation process in Ukraine, being both a condition and a goal of reforming the state. It is a necessary condition because deep transformations require concentration of all forces and means on solving creative tasks. Their distraction to neutralize or fend off threats significantly complicates, and sometimes makes it impossible to successfully move along the chosen path.

The experience of ensuring national security proves that this provision cannot be a onetime act. On the contrary, it is a continuous process of developing security systems, improving methods, ways and mechanisms of monitoring, identifying potential dangers and threats, developing and implementing effective counteraction to the whole range of existing and projected threats. Security can be ensured only with the integrated application of the entire arsenal of available forces and means. The greatest effect is achieved when all the forces, means and methods used are combined into a single, coherent mechanism. Security system alone cannot provide the necessary level of the country's security without proper training and provision of the necessary forces and means, without participation of the relevant authorities and the necessary legal, organizational and technical measures. An important role in creating an effective security system is played by the timely development and implementation of qualitatively new conceptual and regulatory legal documents in the field of national security.

The state of security in the Ukrainian society is characterized by breaking basic social ties: family, economic, informational, cultural, spiritual, interethnic and others. Under the influence of a number of negative factors in Ukraine there is a critical decline in resilience to national security challenges. Analysis of this country's security situation shows that while maintaining existing trends, the danger to the existence and development of Ukraine as a 
welfare state capable of ensuring a dignified life and free human development in accordance with the Constitution increases.

According to the resource the Global Economy.com that provides business and economic data for 200 countries of the world, in 2013 security threats index of Ukraine (0 (low) - 10 (high)) accounted for 4.40, ranking the country 14th in Europe and 131st in the world. In 2020 this country's security threats index increased to 7.00 placing it the 3rd and 48th respectively (See Fig. 1).

Recent values

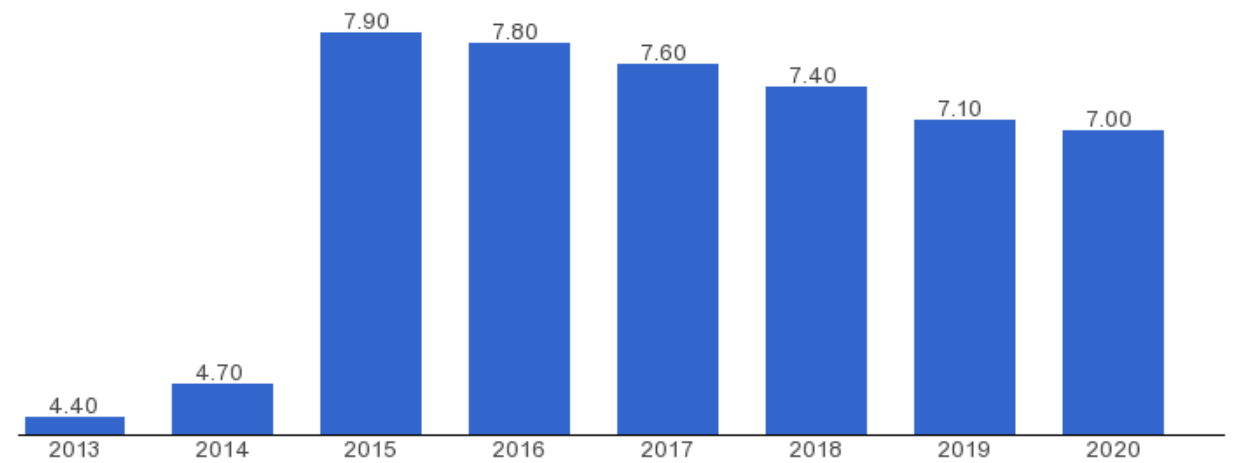

Fig. 1. Dynamics of security threats index of Ukraine, 2013-2020, (0 (low) - 10 (high)) [39].

According to the Control Risks, a specialist risk consultancy, in 2021, Ukraine is forecast as a country with the high political and security risk, with extremal risks on its eastern territories (See Fig. 2).

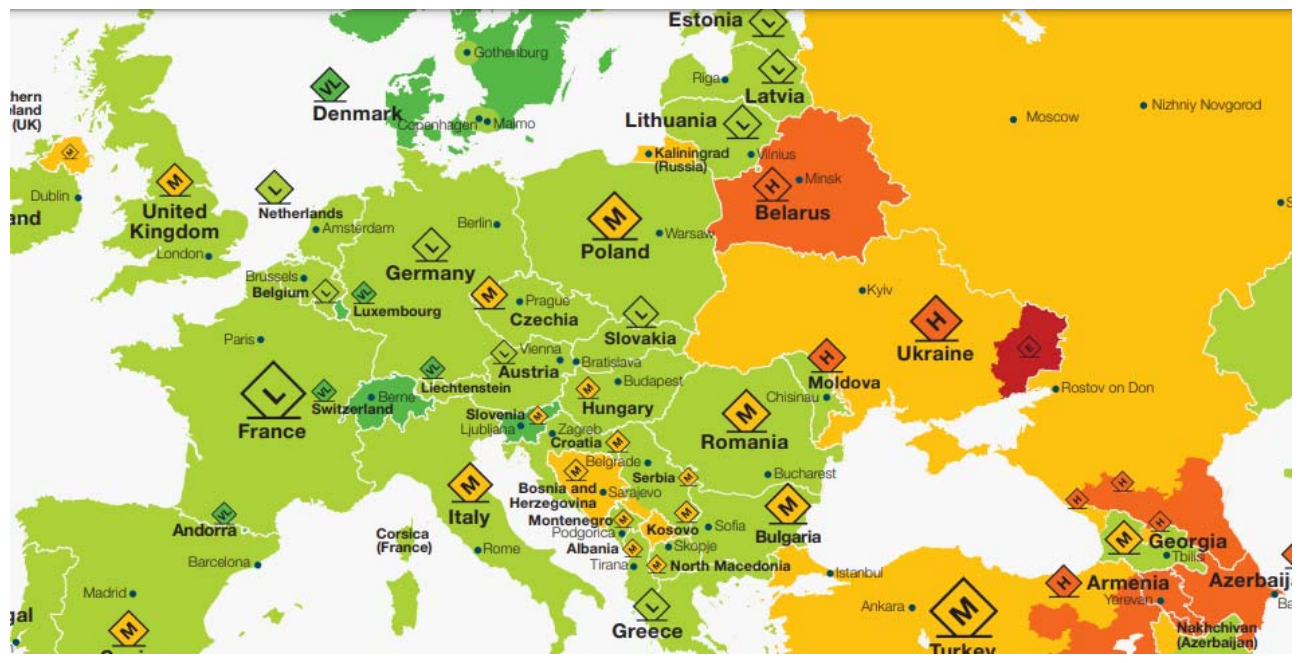

Fig. 2. Riskmap 2021 (a fragment). The forecast of political and security risk for Europe [40].

These data emphasize the urgency of the national security issues for the country and the topicality of sustainable management in this domain. As an integral characteristic of the state system, as the national security system includes a number of subsystems - the most important, interconnected structural components of security, reflecting the functioning of certain areas of the state: investment, innovation, social, energy and environmental. This list 
can be supplemented or clarified both by components and by indicators. In turn, national security is achieved by such a level of development and such an immunity condition of the country and its citizens, which fully meets the needs of the state and creates terms for innovative and sustainable development. For synergy with implementing the country's Sustainable Development Goals 2030, the creation of an effective system of national security of Ukraine, the modernization of its policy in accordance with today's requirements is a necessity for the future well-being of citizens. The problem of improving the mechanism for ensuring the assessment of national security on the basis of timely detection and prediction of threats to the national security system by monitoring the internal and external environment, geo-political and geo-economic challenges remains extremely acute.

\section{Discussion}

Managing sustainability of national security is a special type of activity aimed at streamlining, coordinating the collective actions of people to achieve a common goal using available resources systematically and reasonably and operating socially responsibly. The objective needs for the emergence and development of managing sustainable development in the security sector are due to societal needs.

The goals of managing security sustainability are differentiated depending on the levels of its implementation. Thus, the purpose of managing sustainability of the entire national security system is to ensure the effective functioning and development of all relevant structures operating in the field of security, solving common security tasks by creating and organizing special enterprises, public organizations that manage various areas. At the individual level, the goal of managing security sustainability is to ensure the safety of each person.

In managing security sustainability, both the managing subsystem (subject of management) and the managed subsystem (object of management) are mostly represented by people - individuals or those united in different communities, who represent certain social relations. Given an internal unity between the subject and the object of national security sustainability management, it should be noted that the subject of management always deals with the changing object and tries to keep up with it in its development. Yet, they are not always compatible as the managing subsystem may lag too far behind in its development from the managed one. Such situation has been lately observed due to threats and dangers increasingly emerging in the information domain, and entities managing national security sustainability do not have sufficient knowledge and resources to ensure the appropriate level of information security.

In most cases, managerial relations are governed by the rules of law that regulate the competence of the subject of management, its organizational structure. As a result, they acquire the character of legal relations, which personify the legal rights and obligations of the parties. However, managerial activity is closely related to the elements of creativity, which are not fully amenable to fixation and regulation. In addition, other social norms and rules of an organizational nature also take part in the regulation of managerial relations. Thus, consideration of the essence and content of managing sustainable development of national security allows defining it as an objectively necessary type of activity, consisting of conscious and purposeful influence of management entities on various objects in order to ensure the sustainability of their security in accordance with objective patterns of development.

Given the problems of forming and establishing a common national identity for all ethnic, cultural, religious, linguistic, etc. groups of the population in Ukraine, special attention should be paid to strengthening the authority of the state as a tool for exercising and protecting the rights and freedoms of citizens. In this context, the focus should be on: restoring trust in the state as a set of institutions designed to guarantee the protection of the 
rights and freedoms of Ukrainian citizens; carrying out constitutional reform, the purpose of which will be to balance the powers of all branches of government. This will make it possible to minimize intergovernmental conflicts, which now give severe blows to the authority of the state; to improve the effectiveness of the fight against corruption; to develop and implement a strategic priority to achieve national unity and consolidation of society by overcoming both objective and artificial contradictions of socio-cultural, religious, ethnic, linguistic, interregional and regional nature, to launch programs with a clearly defined set of measures and circle of performers, to promote the consolidation of Ukrainian society; changing the emphasis of Ukraine's security policy from the dominance of its political, economic and military component towards the systematic consideration of problems in humanitarian area; to create a strategy for the humanitarian development of the state, which would define a clear vector of public policy in the humanitarian sphere in general and in its security sector.

The sustainable system of national security should form a set of interconnected and mutually conditioned subjects of national security (state officials, public authorities and local governments, state institutions and establishments, forces and means of the security sector, civil society institutions, individual citizens) and mechanisms (institutional, organizational, legal and others), which ensure their coordinated activities on the basis of current legislation. The main purpose of managing sustainability of national security is to transform national security policy into purposeful coordinated activities of public authorities, local governments, components of the security sector (measures of political, legal, military and other nature), aimed at realizing national interests (including detection, forecasting, prevention and neutralization of threats to the security of the individual (citizen), society and the state. Achieving this goal involves a number of tasks, including: development (refinement) of concepts, doctrines, strategies, other guidelines, including scientifically sound proposals and recommendations for sustainability in creating national security policy, its preparation and support in readiness to be used in accordance with the regular purpose and coordination of the forces and means of the security sector, as well as its personnel, logistical, financial and other support; localization, de-escalation and settlement of conflicts in various spheres of life, as well as the elimination of their consequences; implementation of measures together with international organizations to ensure the sustainable development of the international and national security; comprehensive monitoring of factors that affect national security, including the identification, forecasting and assessment of threats and opportunities in the context of pursuing national interests; control over the implementation of measures to ensure national security, evaluation of the effectiveness of actions and costs of these measures. These tasks primarily involve the development and implementation of a sustainable system of measures aimed at protecting national interests.

At the same time, it should be noted that the focus primarily on protecting these interests forms a policy of national security, the essence of which is expectations and survival. Such a policy is hopeless as it gives initiative and, therefore, benefits to the party that is seen as a likely source of threats. Therefore, given that Ukrainian legislators understand the national interests' immunity not only as protection but also as ensuring sustainable development of society, it is also important for the subject of the national security system to take persistent efforts to create more favourable conditions for pursuing these interests.

The principles of such a system's construction and operation are determined by the approaches to ensuring national security, which are defined by law. They comprise, inter alia: compliance with the balance of vital interests of man, social group, society and the state and ensuring their mutual responsibility for addressing issues of national security; ensuring the rule of law, as well as the priority of negotiated (peaceful) means in resolving conflicts of social, interethnic, interfaith nature at the national and international levels; respect for the sovereignty of other states and non-interference in their internal affairs; ensuring the adequacy of measures to protect national interests against existing threats; active involvement 
of civil society institutions and the media in the process of developing and implementing national security policy; and support at the appropriate level of research and training in the field of national security.

Public administration in the field of national security is a specific type and inseparable component of overall public administration, which covers the social, economic, humanitarian and political spheres of public and state life and which consists in the purposeful activities of national security actors, which, within current legal framework and using the available capabilities of the state (diplomatic, military, economic, intellectual, information and others), develop and implement authoritative, regulatory, coordinating, controlling and regulatory public administration influencing national security facilities. Meeting the needs of security at the individual, social, national, international levels involves the application of a systemsynergetic approach to take into account a number of factors that affect the sustainable development of the social system, including:

- a steady-growing role of environmental factors and economic component which requires an appropriate level of international cooperation and further knowledge and consideration in the development of strategies for the sustainable development of evolutionary laws of nature and society and, accordingly, the choice of development strategy that achieves harmony of environmental, social, economic, political relations;

- the need to simultaneously take into account the cultural and historical features of national development and the components and characteristics of international security;

- contradictory changes in universal, national, group, personal interests and value orientations, and hence the unpredictability and uncertainty of socio-political transformations, as the change of any subsystem of the social organism often causes spontaneous change of many of its subsystems;

- economic globalization and the development of information technologies, which lead to the proliferation of virtual interest groups and reduce the ability of states to manage effectively, which is increasingly under pressure from a mass culture, often hostile to national achievements.

The public administration component of national security has its own specific features, according to which its functions are objectively "present" in every sphere of public and state life. Like any social and legal entity, the system of public administration in the field of ensuring sustainability of the national security of Ukraine has its own purpose (proper development and functional activity of the object of influence), a number of principles and functions, the subjects' composition. At the same time, the system solves problems due to its inherent institutional methods and means, i.e., uses certain organizational, legal and functional mechanisms. Also, this system handles foreign policy threats to national security, national interests, values and needs (objects), state and non-state actors to ensure the domestic and foreign policy of our state.

In accordance with the priorities of domestic and foreign policy to ensure the national security of Ukraine and its purpose, there can be determined the general functions of public administration in the field of ensuring national security of Ukraine under conditions of instability:

- strategic forecasting in the context of new threats to national security of Ukraine;

- strategic planning to ensure sustainability of national security in the domestic and foreign policy spheres;

- organization of public administration to implement sustainability in the field of domestic and foreign policy.

Given the functions entrusted to public administration to ensure sustainability of national security, the system of public management should be directed to the following priorities: 
- to ensure the integrity of Ukraine's foreign policy in the context of forming the national security of this country in the international community;

- to protect the sovereignty, territorial integrity and inviolability of the state border;

- to pursue the strategic course of accessing the EU as the highest priority of the state policy of Ukraine;

- to neutralize global challenges and threats in the field of national security of Ukraine;

- to ensure the political and diplomatic influence of Ukraine in the framework of international security;

- to intensify Ukraine's participation in the global collective security;

- to create a positive image of this country on the world stage;

- to implement international regulations to ensure sustainability of national security;

- to carry out unified coordination and interaction among public administration bodies,

- to promote political, economic, scientific, humanitarian, social, cultural and other national interests globally;

- to create an effective mechanism of assisting citizens of Ukraine abroad;

- to increase the export potential of Ukraine, providing Ukrainian producers and exporters with the opportunity to capture new markets, attract foreign investment in the state economy.

These measures are to be implemented through forming a single National Security Strategy of Ukraine, the main purpose of which should be the desire to protect the national interests of the state on the global arena.

Such approach to national stability implies that it is grounded on improving crisis management in the field of protecting the population and critical objects of the state from various threats and dangers (especially natural, man-made, biological, terrorist or military), as well as continuity of implementing critical functions of the state (in particular, governance, energy, water and food supply, transport and communications, primary health care, the ability to cope with mass displacement or significant human losses, etc.).

The existing recommendations of NATO and EU countries on sustainable development are aimed primarily at strengthening crisis management, which involves all civilian, military, public and private institutions, a clear division of responsibilities and proper coordination before, during and after the crisis in peacetime and wartime. There are many vulnerabilities in Ukraine due to insufficient consolidation of society, inefficiency of public administration, incomplete reform of the security and defence sector and decentralization processes, systemic shortcomings of the national economy, etc.

Ukraine's efforts towards sustainable development should be aimed at improving crisis management, community resilience, economic stability, and social stability. Permanent mechanisms of interaction between state and local authorities, non-governmental organizations, private business and international partners on ensuring national sustainability (at the national and regional levels) should be established, and permanent bilateral channels of state communication with the population should function.

In this context, it is important to conduct periodic interdepartmental exercises and trainings with the participation of the population and other activities in order to raise awareness and preparedness to respond to a wide range of threats, create the necessary reserves and develop capabilities in various fields, legal support of relevant processes, including: legislative regulation of strategic planning issues in the country taking into account the principles of sustainable development, national security and sustainability. 


\section{Conclusion}

Summing up, sustainable development and national security are interrelated and interdependent categories. The integrated level of national security of Ukraine correlates with the goals of sustainable development. The country's resilience and its resistance to threats to national security are a necessary condition for implementing a focused development strategy 2030. Analysis of the causes and indicators of crises and weaknesses of national security should help mobilize resources and political will at the national level to form effective policies to create a stable system. Less than ten years remain before the 2030 UN Sustainable Development Agenda expires, and Ukraine must do its best to go its own way as effectively as possible. Successful solution of tasks fateful for Ukraine is possible under the condition of unity and capacity of state power and society. The dynamics and scale of change in the modern world dictate the urgent need for the country to develop a unified system of knowledge about sustainable development of national security and the feasible ways to ensure it in the short and long run.

It can be concluded that studying the state-administrative component of national security is crucial for modern sustainable development of the statehood, because the state cannot exist without proper sustainability. The historical emergence of national security problems is synchronized with the way sustainable development takes place.

Ensuring national stability is one of the priority areas of Ukraine's national security policy at the present stage. This is due to the need to ensure the readiness of the state and society to respond to a wide range of threats of various origins, as well as the continuity of major processes in the state. Ukraine has a significant potential for resilience, as evidenced by its experience in countering Russian aggression. However, systemic mechanisms to ensure sustainability of the country's development have not yet been established. Their introduction will simultaneously strengthen and develop Ukraine's national security system. Based on the complex security environment of Ukraine and the specific features of sustainable development of the state and society, ensuring national stability should include a comprehensive approach to countering a wide range of threats, effective cooperation of government agencies (security and defence sector and others), communities, business and the population. response to threats and overcoming their consequences, as well as coordination of such activities, high level of citizens' and officials' awareness of the nature and urgency of threats/dangers, as well as the procedure in case of their occurrence, high readiness of the state and society to respond to any threats and the ability to resist, the continuity of the main processes in the state (government, the provision of critical services to society, business processes, etc.), reliable and permanent bilateral channels of communication between the state and the population. All this contributes to creating the necessary capabilities and forms the ability of society and the state to quickly adapt to changes in the security environment and maintain sustainable functioning, in particular by minimizing external vulnerabilities, and quickly recover from the crisis to the desired balance.

\section{References}

1. G. Brundtland, Report of the World Commission on Environment and Development: Our Common Future. United Nations General Assembly Document A/42/427 (1987)

2. Human Development Report 1994. Published for the United Nations Development Programme (UNDP) New York Oxford, Oxford University Press (1994)

3. G. E. Smith, In Search of Sustainable Security. Linking National Security, Human Security, and Collective Security to Protect America and Our World. Washington DC: The Center for American Progress (2008) 
4. J. Kirshner, Globalization and National Security (Routledge, London, 2013)

5. W. R. Blackburn, The Sustainability Handbook (Environmental Law Institute Washington, 2007)

6. Sustainability and National Security (eds. J. Hartman, K. Butts, B. Bankus, S. Carney). U.S. Army War College, Center for Strategic Leadership (January 2012)

7. J. Hartman, Sustainability and National Security (2013)

8. K. Butts, B. Bankus, Sustainability: A Lens for National Security (2013).

9. Y. Kharazishvili, O. Grishnova, B. Kamińska, Virtual Economics, 2(2), 7-36 (2019)

10. S. Khagram, W. Clark, D. Firas Raad, Journal of Human Development 4(2), 289-313 (2003)

11. D. Pearce, E. Barbier, Blueprint for a Sustainable Economy (Earthscan Publications Ltd, London, 2000)

12. S. Wasserman Goodman, The Environment and National Security. Remarks as Prepared for Delivery, National Defence University, August 8 (1996)

13. B. R. Allenby, Environmental dimensions of national security, in National Security Environmental Threats and National Security: An International Challenge to Science and Technology: Proceedings from the Workshop at Monterey, California, December (1996)

14. H. Dzwigoł, M. Dzwigoł-Barosz, Z. Zhyvko, R. Miskiewicz \& H. Pushak, Journal of Security and Sustainability Issues, 8(3), 307-317 (2019)

15. T. Polozova, V. Musiienko, O. Storozhenko, O. Peresada, \& N. Geseleva, Journal of Security and Sustainability Issues, 8(3), 387-397 (2019)

16. D. Lutterbeck, European Security, 14(2), 231-253 (2005)

17. T. Limba, A. Stankevičius, A. Andrulevičius, Entrepreneurship and Sustainability Issues, 6(3), 1528-1535 (2019)

18. V. Antonov, Constitutional and Legal Principles of National Security of Ukraine:A Monograph (TALKOM, Kyiv, 2017)

19. O. Dzioban, National Security: Worldview and Theoretical and Methodological Principles: A monograph (Pravo, Kharkiv, 2021).

20. V. Lipkan, Security Study (European University, Kyiv, 2003)

21. O. Potiekhin, I. Todorov, Globalization of Security (Knowledge, Donetsk, 2011)

22. H. Sytnyk, National Security of Ukraine (methodological aspects, state and development trends) (Presa Ukrainy, Kyiv, 2000)

23. V. Shpak, S. Tabachnikov National Security of Ukraine in the Challenges of Contemporary History (DP "Express-obiava", Kyiv, 2020)

24. Y. Kharazishvili, Systemic Security of Sustainable Development: Assessment Tools, Reserves and Strategic Implementation Scenarios. A monograph (Institute of Industrial Economics of the National Academy of Sciences of Ukraine, Kyiv, 2019)

25. Y. Kharazishvili, A. Kwilinski, O. Grishnova, H. Dzwigol, Sustainability, 12(21), 8953 (2020)

26. O. Sukhodolia, Scientific Journal the Academy of National Security, 3(4), 30-63 (2019)

27. O. Sukhodolia, Energy Security: Operational Highlights, 11, 25-34 (2017)

28. A. Kwilinski, V. Tkachenko, A. Kuzior, Journal of Security and Sustainability Issues, 9(2), 561-570 (2019)

29. N. Dalevska, V. Khobta, A. Kwilinski, S. Kravchenko, Entrepreneurship and Sustainability Issues, 6(4), 1839-1860 (2019) 
30. R. Shapoval, V. Nastyuk, O. Bezpalova, N. Khrystynchenko, Journal of Security and Sustainability Issues, 8(1), 45-54 (2018)

31. Declaration on the State Sovereignty of Ukraine, https://zakon.rada.gov.ua/laws/show/55-12\#Text (1990)

32. Constitution of Ukraine, https://www.justice.gov/sites/default/files/eoir/legacy/2013/11/08/constitution_14.pdf (2004)

33. Goals of Sustainable Development and Ukraine, https://www.kmu.gov.ua/diyalnist/cilistalogo-rozvitku-ta-ukrayina (2015)

34. On the Goals of Sustainable Development of Ukraine for the Period up to 2030. Decree of the President of Ukraine No $722 / 2019$ as of September 30, 2019, https://www.president.gov.ua/documents/7222019-29825 (2019)

35. Law of Ukraine "On National Security of Ukraine", https://zakon.rada.gov.ua/laws/show/2469-19\#Text (2018)

36. National Security Strategy of Ukraine. Decree of the President of Ukraine No392/2020 of September 14, 2020, https://www.president.gov.ua/documents/3922020-35037 (2020)

37. On the decision of the National Security and Defence Council of Ukraine of March 25, 2021 "On the Strategy of Military Security of Ukraine". Made effective by the Decree of the President of Ukraine No121/2021 of March 25, 2021, https://www.president.gov.ua/documents/1212021-37661 (2021)

38. About the Strategic Defence Bulletin of Ukraine. Made effective by the Decree of the President of Ukraine No 240/2016 of June 6, 2016, https://zakon.rada.gov.ua/laws/show/n0006525-16\#Text (2016)

39. Ukraine: Security Threats Index, https://www.theglobaleconomy.com/Ukraine/security_threats_index/ (2021)

40. The Risk Ratings 2021, https://www.controlrisks.com/-/media/corporate/files/riskmap2021/riskmap-2021-map-regions-world-a3v2.pdf (2021) 